\title{
ESTIMATING FLASH FLOOD PEAK DISCHARGE IN GIDRA AND PARNÁ BASIN: CASE STUDY FOR THE 7-8 JUNE 2011 FLOOD
}

\author{
PAVLA PEKÁROVÁ ${ }^{1)}$, ALEŠ SVOBODA ${ }^{1)}$, PAVOL MIKLÁNEK ${ }^{1)}$, PETER ŠKODA $^{2)}$, \\ DANA HALMOVÁ ${ }^{1)}$, JÁN PEKÁR ${ }^{3)}$ \\ ${ }^{1)}$ Institute of Hydrology, Slovak Academy of Sciences, Račianska 75, 83102 Bratislava, Slovakia; Mailto: pekarova@uh.savba.sk \\ ${ }^{2)}$ Slovak Hydrometeorological Institute, Jeséniova 17, 83315 Bratislava, Slovakia. \\ ${ }^{3)}$ Department of Applied Mathematics and Statistics, Faculty of Mathematics, Physics and Informatics, Comenius University, \\ Mlynská dolina, 84248 Bratislava, Slovakia.
}

We analyzed the runoff and its temporal distribution during the catastrophic flood events on river Gidra $\left(32.9 \mathrm{~km}^{2}\right)$ and Parná $\left(37.86 \mathrm{~km}^{2}\right)$ of the 7 th June 2011 . The catchments are located in the Small Carpathian Mountains, western Slovakia. Direct measurements and evaluation of the peak discharge values after such extreme events are emphasized in the paper including exceedance probabilities of peak flows and of their causal flash rainfall events. In the second part of the paper, plausible modeling mode is presented, using the NLC (Non Linear Cascade) rainfall-runoff model. Several hypothetical extreme flood events were simulated by the NLC model for both rivers. Also the flood runoff volumes are evaluated as basic information on the natural or artificial catchment storage.

KEY WORDS: Flash Floods, Gidra and Parná Rivers, Post-Flood Event Analysis, Runoff Modeling.

Pavla Pekárová, Aleš Svoboda, Pavol Miklánek, Peter Škoda, Dana Halmová, Ján Pekár: ODHAD VRCHOLOVÝCH PRIETOKOV V POVODÍ GIDRY A PARNEJ - PRÍPADOVÁ ŠTÚDIA POVODNE ZO 7.-8. JÚNA 2011. J. Hydrol. Hydromech., 60, 2012, 3; 26 lit., 9 obr., 5 tab.

Predložený príspevok analyzuje tvorbu a priebeh odtoku počas katastrofickej povodňovej situácie na Gidre $\left(32,9 \mathrm{~km}^{2}\right)$ a na Parnej $\left(37,86 \mathrm{~km}^{2}\right)$ dňa 7. 6. 2011. Povodia týchto tokov sa nachádzajú v Malých Karpatoch na západnom Slovensku. V príspevku sa kladie dôraz na priame zameranie a vyhodnotenie kulminačných prietokov po výskyte takýchto povodní. Diskutujú sa problémy vyjadrenia pravdepodobnosti prekročenia kulminačných prietokov a dažd’ov, ktoré ich spôsobili. V druhej časti príspevku je prezentovaný možný spôsob modelovania povodne jednoduchým zrážkovo-odtokovým modelom NLC. Daným modelom NLC sú následne simulované prietoky Gidry v stanici Píla a Parná v stanici Horné Orešany za extrémnej hypotetickej zrážkovej udalosti. Hodnotené sú objemy odtoku počas povodní, ako základný údaj pre reálny odhad ich prirodzeného alebo umelého zadržania.

KLÚČOVÉ SLOVÁ: bleskové povodne, rieky Gidra a Parná, analýza povodní, modelovanie odtoku.

\section{Introduction}

Flash floods on small rivers belong to the most significant natural hazards. Such are those which in the last 15 years influenced almost whole Europe, and caused also losses of lives, not to speak about losses of property amounting to millions Euro. Such floods are caused mostly by extreme high summer storm rains, hitting relatively small areas, frequently without rainfall and water level recording equipment. Therefore, flash floods reconstruction frequently causes many problems and uncertainties (e.g. river Malá Svinka 1998 flood (Svoboda and Pekárová, 1998), or flood on the Belá
River in the High Tatras (Pekárová et al., 2010)). On the flash floods, there is still a lack of sufficient information (Gaume et al., 2009, 2010). Therefore, description and analysis (also by means of rainfallrunoff models) of every flood event is extremely important (Dzubák et al., 1995; Štastný and Majerčáková, 2001; Kliment et al., 2011; Blaškovičová et al., 2011; Šraj et al., 2010; Braud et al., 2010; Aristeidis et al., 2011; Parajka et al., 2010). The HYDRATE project was proposed to deepen our knowledge on the flood generating mechanisms, (Borga et al., 2011). Its final aim was to enhance the capability of flash flood forecasting in ungauged basins by exploiting the extended 
availability of flash flood data and the improved process understanding. The effort of Borga et al. (2011) provides a review of the work conducted within the HYDRATE project with a special emphasis placed on how this research can contribute to guide the policy-life cycle concerning flash flood risk management.

In our study, we analyze the flash flood formation and its temporal evolution, during the extreme flood situations on the Gidra and Parná rivers (small streams in the Small Carpathians) on the 7th June 2011. Using the NLC rainfall-runoff model, we have simulated flood flows from hypothetical extreme heavy rainfall for concerned rivers at the Píla station (Gidra) and Horné Orešany station (Parná). Problems encountered with determining the peak flows with extremely low exceedance probability on the small rivers are also discussed.

\section{Description of the Gidra and Parná basins}

On the 7th June 2011, in the afternoon, on the southeastern slopes of the Small Carpathian range, a catastrophic flood situation developed, hitting the upper catchments of the following small streams: Vištuk creek, Gidra, Štefanová creek, Podhájska creek, and Parná (Fig. 1). The resulting flood waves caused heavy damage in the following communes, located at the foot of the Small Carpathians: Píla, Častá, Dol’any, Horné Orešany and Lošonec.

The Gidra and Parná small streams are located in the southern part of the Small Carpathians, western Slovakia (Pekárová and Pekár, 1998). These mountains belong to southern corn of the inner Carpathian massive. The Small Carpathians are built of metamorphic rocks such as gneiss, migmatites, granotoids, and phyllites.

In their upper parts, the streams flow through the more or less original beech forest environment. Single human interventions are a small dam on the Parná and fishponds on the Gidra, upstream of the water level observation stations. The highest point in the catchments reaches $694 \mathrm{~m}$ a.s.l. (hills Jelenec and Geldek on the Gidra and Parná basins divide). After leaving the Small Carpathian mountain range, the rivers flow through an agriculturally used land and also through some of the local communities.

\subsection{Discharge analysis}

The Slovak Hydrometeorological Institute (SHMI) established water level gauging stations on the Gidra and the Parná in 1956. Their basic geographic characteristics and water balance are presented in Tab. 1a),b). Discharge characteristics of both rivers at the mentioned stations were evaluated from the SHMI daily discharge database for the period 1961-2010. Selected discharge characteristics are given in Tab. 2a),b).

Since 1960, mean annual flows in both stations have slowly decreased. The recent years discharge rise still has not outbalanced the long-term decrease (Fig. 2a)). In most rivers of Slovakia, decrease of runoff has been observed within the 1961-2010 years. After year 2010 with high precipitation, this runoff decrease will probably crease.

In terms of peak discharge, the highest 1961-2010 Gidra peak $8.694 \mathrm{~m}^{3} \mathrm{~s}^{-1}$ occurred on 7 th July, 1997 with $92 \mathrm{~cm}$ gauge water stage (Fig. 2b)). The highest water level $120 \mathrm{~cm}$ occurred during the spring snowmelt on 29th March 2006, with 8.023 $\mathrm{m}^{3} \mathrm{~s}^{-1}$ peak. On the Parná River, the highest peak within the same period was $8.985 \mathrm{~m}^{3} \mathrm{~s}^{-1}$ and it was observed on 29th March 2006 at the highest observed water stage $125 \mathrm{~cm}$.

\subsection{Atmospheric precipitation}

There are no precipitation stations located directly in the Gidra and/or Parná upper river catchments. The nearest one is located at the Comenius University astronomical observatory in Modra-Piesok on Tisové Rocks, at an altitude of $531 \mathrm{~m}$ a.s.l. (see Fig. 1). It has been in operation since 1988. There are another SHMI stations in the vicinity, however not in the mountainous area, at Častá and Smolenice (ca $250 \mathrm{~m}$ a.s.l. since 1901) communities. The longterm mean annual precipitation at Modra-Piesok observatory station reached $851 \mathrm{~mm}$ within the 1989-2007 years, the lowest annual mean was $532 \mathrm{~mm}$ in 2003, and the highest one was $1108 \mathrm{~mm}$ in 2002 .

On the 7th June 2011, the daily precipitation amount of the $104 \mathrm{~mm}$ was observed at ModraPiesok station. Such daily amount is not unusual in the Small Carpathian region. In Limbach station, $147 \mathrm{~mm}$ of daily precipitation was observed in 1957, in Myjava station $142 \mathrm{~mm}$ in 1954. In the Trnava station (school), even $162.8 \mathrm{~mm}$ daily precipitation amount was observed in 1951. According to $\breve{S} a m a j$ et al. (1985), $104 \mathrm{~mm}$ daily precipitation amount in Limbach station represents value with $T$ $=50$-years return period and in Smolenice station an event with $T=100$-years return period.

In Tab. 3, the daily precipitation amounts are presented for various $T$-year return periods, calcu- 
lated according to the log-Pearson type III exceedance probability curve.

The daily rainfall amount - particularly in cases of small catchments - is not a suitable characteristic describing the flash flood storm rain causing an extreme flood. During such precipitation, the largest part of the daily amount falls within a substantially shorter time, often within 1-2 hours (Šraj et al., 2010). It is therefore necessary, to evaluate such precipitation amounts in relation to their duration, using the rainfall intensity duration frequency curves.

In relation to the construction of hydraulic structures on small streams, as first in Slovakia in early forties of the 20th century, Dub (1941) studied the hydraulic structures construction economical design on small streams. He pointed out, that for indirect peak flow values calculation on small streams, methods used for the sewerage systems hydraulic design in large cities should be preferred. On the basis of at-that-time available precipitation records, he derived series of the mentioned rainfall intensity duration frequency curves for our various regions (for exceedance probabilities $p=1.0$ and $p=0.5$ $\%)$. Eventually, the Gidra and Parná basins, as well as other basins suffering recently by high flash floods, by their catchment areas are not much different from those of the larger cities sewerage systems.

$\mathrm{T}$ a b 1 e 1a) Basic physiographic characteristics of the basins in question; $A$ - catchment area, $L$ - valley length, $A / L^{2}-$ basin shape characteristic according to HP ČSSR (1965).

\begin{tabular}{lcccccc}
\hline Stream: location & $\begin{array}{c}A \\
{\left[\mathrm{~km}^{2}\right]}\end{array}$ & $\begin{array}{c}L \\
{[\mathrm{~km}]}\end{array}$ & $A / L^{2}$ & River km & Elevation [m a.s.1.]-zero & Forestation \\
water level & {$[\%]$} & 95 \\
\hline Gidra: Píla & 32.95 & 7.9 & 0.5 & 33.3 & 270.04 & 95 \\
Parná: H. Orešany & 37.86 & 11.0 & 0.31 & 26.8 & 234.68 & 95 \\
\hline
\end{tabular}

T a b 1 e 1b) Basic water balance characteristics of the selected basins, $P$ - basin mean annual precipitation 1931-1980 (Hlubocký, 1989), $R$ - runoff, $K_{r}$ - runoff coefficient, $q_{a}$ - mean specific runoff, $Q_{a}$ - mean discharge in $1961-1980$ according to Adámyová (1989).

\begin{tabular}{lccccc}
\hline Stream: location & $\begin{array}{c}P \\
{[\mathrm{~mm}]}\end{array}$ & $\begin{array}{c}R \\
{[\mathrm{~mm}]}\end{array}$ & $K_{r}$ & $\begin{array}{c}q_{a} \\
{\left[\mathrm{~s} \mathrm{~s}^{-1} \mathrm{~m}^{-2}\right]}\end{array}$ & $\begin{array}{c}Q_{a} \\
{\left[\mathrm{~m}^{3} \mathrm{~s}^{-1}\right]}\end{array}$ \\
\hline Gidra: Píla & 1024 & 294 & 0.29 & 9.32 & 0.294 \\
Parná: H. Orešany & 986 & 329 & 0.33 & 10.43 & 0.395 \\
\hline
\end{tabular}

T a b 1 e 2a) Basic characteristics of the 1961-2010 mean annual discharges, Gidra and Parná Rivers; $Q_{a}, Q_{a, \min }, Q_{a, \max }-$ average, minimum, maximum annual discharge, $c_{s}, c_{v}$ - asymmetry, variation coefficients, Med - median value.

\begin{tabular}{lcccccccc}
\hline $\begin{array}{c}Q_{a} \\
\text { 1961-2010 }\end{array}$ & $\begin{array}{c}q_{a} \\
{\left[\mathrm{~m}^{3} \mathrm{~s}^{-1}\right]}\end{array}$ & $\begin{array}{c}Q_{a, \min } \\
{\left[\mathrm{L} \mathrm{s}^{-1} \mathrm{~km}^{-2}\right]}\end{array}$ & $\begin{array}{c}Q_{a, \max } \\
{\left[\mathrm{m}^{3} \mathrm{~s}^{-1}\right]}\end{array}$ & $c_{s}$ & $c_{v}$ & $\begin{array}{c}\text { Median } \\
{\left[\mathrm{m}^{3} \mathrm{~s}^{-1}\right]}\end{array}$ & Trend \\
\hline Gidra: Ṕ́la & 0.29 & 8.86 & 0.11 & 0.55 & 0.47 & 0.33 & 0.28 & -0.0006 \\
Parná: H. Orešany & 0.36 & 9.50 & 0.11 & 0.79 & 0.88 & 0.37 & 0.36 & -0.0027 \\
\hline
\end{tabular}

T a b 1 e 2b) Basic characteristics of the 1961-2010 mean daily discharges, Gidra and Parná Rivers.

\begin{tabular}{lccccccc}
\hline Gidra & mean & $\min$ & $\max$ & 330 -day & 30 -day & $c_{s}$ & $c_{v}$ \\
\hline$Q\left[\mathrm{~m}^{3} \mathrm{~s}^{-1}\right]$ & 0.285 & 0.020 & 6.473 & 0.068 & 0.674 & 5.2 & 1.3 \\
$q\left[1 \mathrm{~s}^{-1} \mathrm{~km}^{-2}\right]$ & 8.6 & 0.6 & 196.4 & 2.1 & 20.4 & & \\
$R[\mathrm{~mm}]$ & 272.7 & & & & & & \\
\hline Parná & mean & $\min$ & $\max$ & 330 -day & 30 -day & $c_{s}$ & $c_{v}$ \\
\hline$Q\left[\mathrm{~m}^{3} \mathrm{~s}^{-1}\right]$ & 0.351 & 0.025 & 7.653 & 0.081 & 0.801 & 5.3 & 1.3 \\
$q\left[1 \mathrm{~s}^{-1} \mathrm{~km}^{-2}\right]$ & 9.3 & 0.7 & 202.1 & 2.1 & 21.2 & & \\
$R[\mathrm{~mm}]$ & 292.3 & & & & & & \\
\hline
\end{tabular}




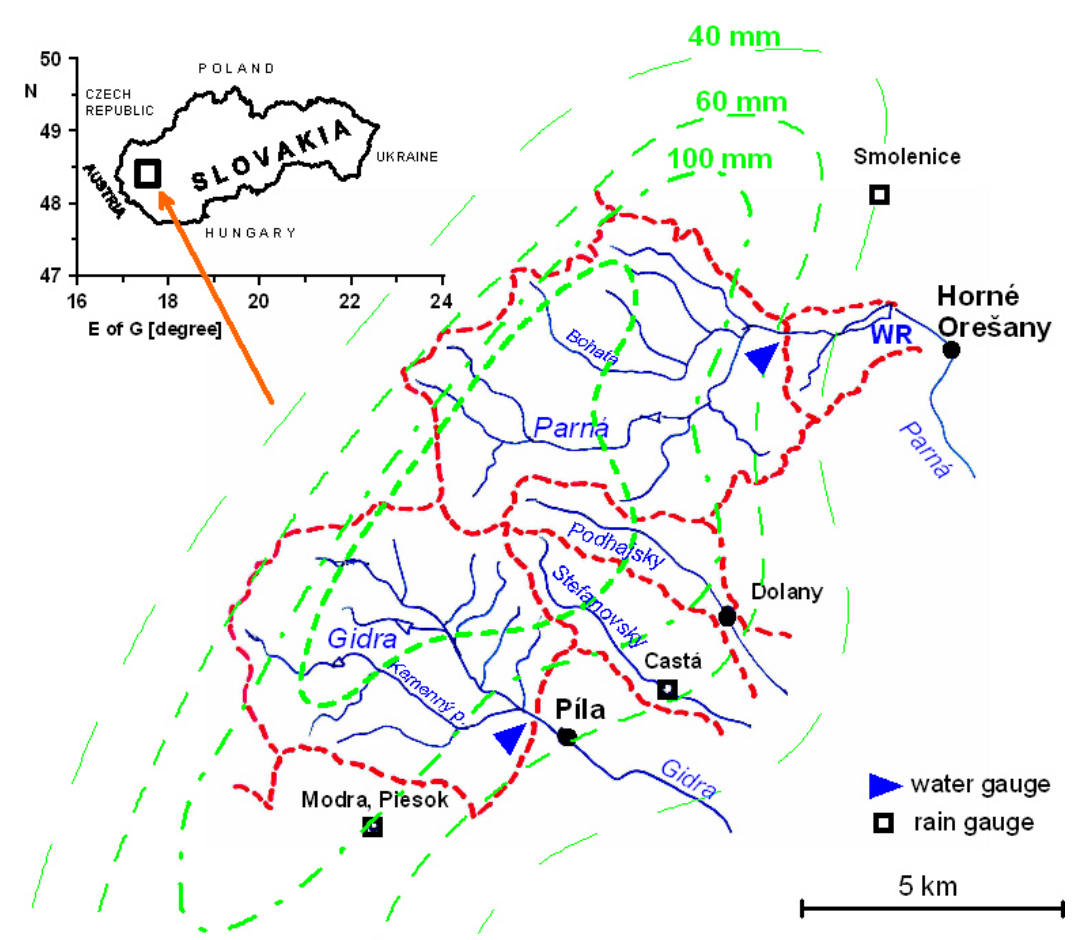

Fig. 1. Gidra and Parná basin scheme up to cross sections at Píla and Horné Orešany. The assumed daily rainfall isolines on 7th June 2011; WR - water reservoir.
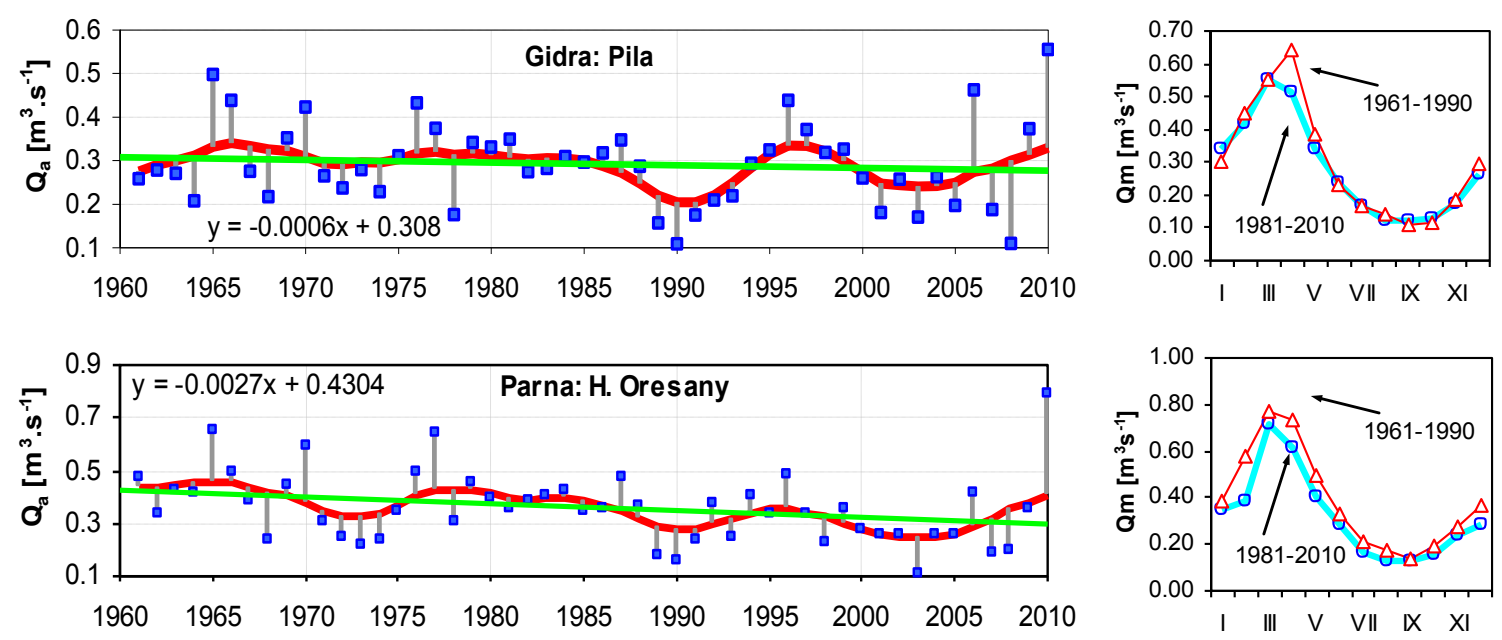

Fig. 2a) Mean annual discharges, multiannual variability, and a long-term linear trend (left). Long-term mean monthly discharges for the two periods: 1961-1990 and 1981-2010 (right). Gidra (upper) and Parná (bottom).
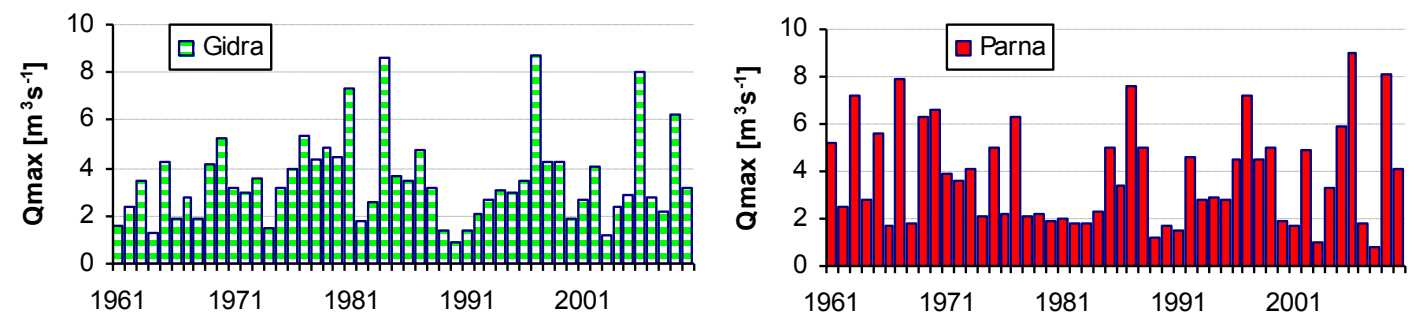

Fig. 2b) Peak annual discharges, Gidra and Parná Rivers, period 1961-2010. 
$\mathrm{T}$ a b 1 e 3. 24-hourly precipitation amounts in millimeters for various return periods $T$, the log-Pearson type III exceedance probability distribution; station altitude in meters a.s.l.

\begin{tabular}{lccccc}
\hline Return period & 50 & 100 & 200 & 1000 & $\begin{array}{c}\text { Altitude } \\
\text { [m a.s.1.] }\end{array}$ \\
\hline Bratislava-Koliba 1951-2007 & 80 & 92 & 105 & 172 & 286 \\
Malý Javorník 1981-2007 & 107 & 128 & 152 & 222 & 586 \\
Modra-Piesok, 1989-2007, 2011 & 122 & 144 & 166 & 229 & 531 \\
\hline
\end{tabular}

\section{Field experimental measurements - peak flow determination}

On 7th June 2011, on both Gidra and Parná, water levels exceeded the river channel embankments into inundation at their water level observation cross sections. At the Gidra flood peak, river width reached 70 meters at the water stage $226 \mathrm{~cm}$ (Fig. 3). So far, the highest observed water stage was $120 \mathrm{~cm}$ during the spring flood on 29th June 2006. Similarly on the Parná, in the same year peak water stage was $225 \mathrm{~cm}$ and flooded river width was even 135 meters.
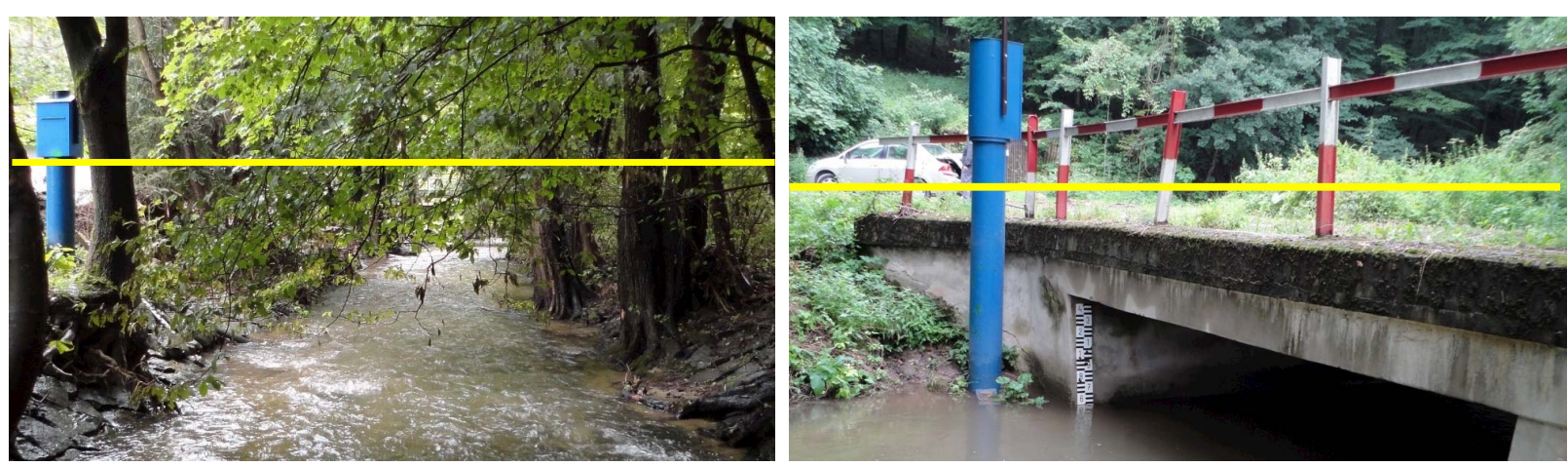

Fig. 3. Water level station Gidra at Píla, water stage $226 \mathrm{~cm}$ - left; water level station Parná at Horné Orešany, water stage $225 \mathrm{~cm}$ - right (7th June 2011).

The Gidra and Parná water level recorders in Píla and Horné Orešany were in full operation and their water level data were available at 15-minutes intervals. However, flood wave discharge evaluation poses problems due to inundation of the wide adjacent land at both stations.

Based on our field flood survey few weeks later, hydraulically calculated Gidra peak was estimated on more than $44 \mathrm{~m}^{3} \mathrm{~s}^{-1}$ and that of Parná on more than $60 \mathrm{~m}^{3} \mathrm{~s}^{-1}$. Using these values, discharge rating curves were derived for water stages on Gidra gauge of over $110 \mathrm{~cm}$, and for Parná of over $120 \mathrm{~cm}$. In Fig. 4 there are presented the 15minutes Modra-Piesok rainfall amounts, and the Gidra evaluated discharges at Píla, as well as those of the Parná at Horné Orešany. This presentation is based on both, our field measurements, and the SHMI water level records.

\subsection{Determination of the T-year design values, based on the 1961-2011 maximum annual discharges}

According to the Slovak sectorial technical standard (OTN ŽP 3112-1:03), for the T-year peak flow values evaluation and determination at discharge observation stations, the highest annual peak for each year is selected from the observed discharges (annual maximum series). In Fig. 5a), extremity of the June 2011 flood wave specific peak discharge is clearly visible. From these series, empirical exceedance probability curves are constructed, and the theoretical curves fitted. For peak discharges in water flows observation stations probabilistic evaluation, crucial point relies on the agreement of the both, empirical and theoretical curves. This depends mostly upon the selection of the theoretical curve type selection, and also upon 
the method used to estimate its parameters. In this study, we used the three parametric Log- Pearson distribution, of its third type.
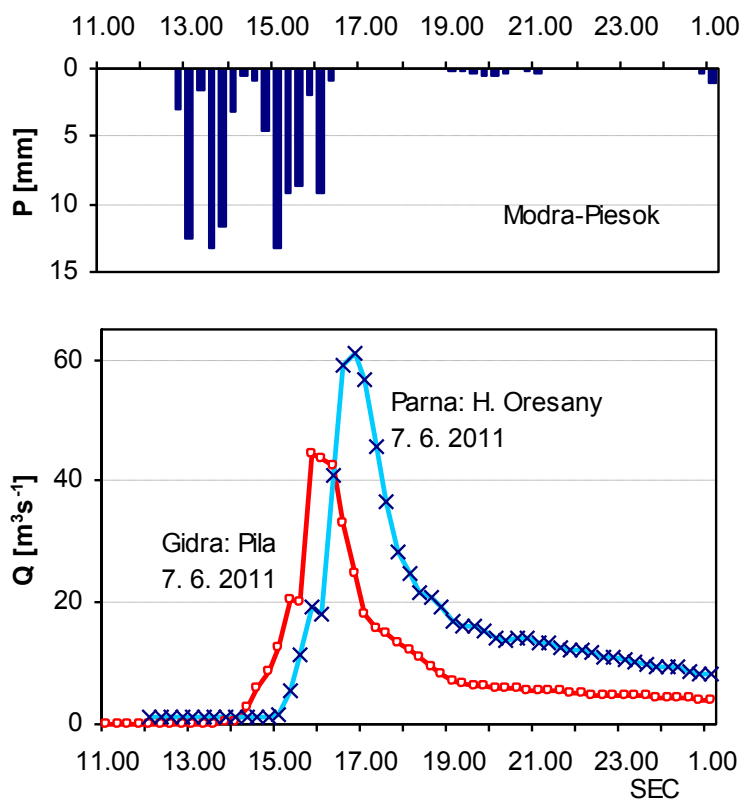

Fig. 4. Time course of the 15-minutes Modra-Piesok rainfall amounts, and computed Gidra and Parná hydrographs at Píla and Horné Orešany, flood on 7th June 2011.

In Fig. 5b), Gidra and Parná annual maximum specific runoff exceedance probability curves (LogPearson, type III) are presented, for the period 1961-2011. We include here also the peaks derived from the June 2011 catastrophic flood. From these data $T$-year values were derived at the Gidra and Parná, presented in Tab. 4.

It should be emphasized that such extreme value will influence significantly the exceedance probability curve form, its shape, significantly also its extrapolation, and thus the $T$-year design maximum discharges and specific runoff. In whatever way it can look extreme, such and even higher values have been on our territory observed already (Vydrňanka, Malá Svinka), and recorded also in Europe many times (Borga et al., 2010). Therefore, such value cannot be excluded from the observation time series, and needs to be accounted for in calculation of the new design discharge values for the small streams upper basins in Small Carpathians.

\subsection{Flood wave volumes}

Assumed the same rainfall amounts hit the Gidra and Parná basin as those observed at the Modra-
Piesok observatory, it is possible to determine the rainfall volumes causing the resulting floods. On the Gidra catchment up to Píla station, it was 3.2 mil. $\mathrm{m}^{3}\left(\right.$ mil. $\left.\mathrm{m}^{3}=10^{6} \mathrm{~m}^{3}\right)$ during the afternoon storm, on the Parná basin up to Horné Orešany it was 3.8 mil. $\mathrm{m}^{3}$ of water. From the calculated 15 minute flood hydrograph ordinates it can be stated, that the total Gidra flood runoff up to the midnight $(24.00 \mathrm{~h})$ was $0.43 \mathrm{mil} . \mathrm{m}^{3}$, which is $13.4 \%$ of the storm rainfall. Similar figure of flood runoff for Parná is 0.685 mil. $\mathrm{m}^{3}$, which represents $18 \%$ of the storm rainfall.

Upstream on the Parná River above the Horné Orešany commune a reservoir has been constructed (WR in Fig.1). It was set into operation in 1994. The catchment area upstream the reservoir is $46.7 \mathrm{~km}^{2}$, the mean discharge at the reservoir inflow during the 1931-1980 period was $0.47 \mathrm{~m}^{3} \mathrm{~s}^{-1}$, its operation storage in 2002 was 3.353 mil. $\mathrm{m}^{3}$, reservoir flooded area $0.496 \mathrm{~km}^{2}$ and dam height $17.5 \mathrm{~m}$. According to Spál (2011), Horné Orešany reservoir during the 7th June 2011 almost completely absorbed the inflowing flood wave (Fig. 6a). Due to that, it protected the lower located communities. Prior to flood wave inflow, by lowering reservoir water level by $1.44 \mathrm{~m}$ below the emergency spillway crest, additional flood retention storage has been created (Fig. 6b)c)). According to the SVP Pieštany (water management administrator) Spál (2011), reservoir stored some 0.817 mil. $\mathrm{m}^{3}$ of water within 3 hours. As to this source, flood wave with the peak of $140-150 \mathrm{~m}^{3} \mathrm{~s}^{-1}$ on the reservoir inflow was transformed to $11.5 \mathrm{~m}^{3} \mathrm{~s}^{-1}$ on its outflow. Parná runoff volume at water level observation station corresponds to that stored during the flood in Horné Orešany water reservoir.

\section{Catastrophic rainfall-runoff scenarios simulation}

A single mathematical model NLC (Non Linear Cascade) was used for this task. It is a conceptual lumped model consisting of storage (linear and nonlinear) elements. Its description can be found in more detail in Svoboda (1987). NLC represents a simple, two-component, rainfall-runoff model capable of modeling groundwater flow and direct runoff. It is of a lumped type, input into the model is total rainfall over the catchment in each time interval. The schematic model structure is shown in Fig. 7. 


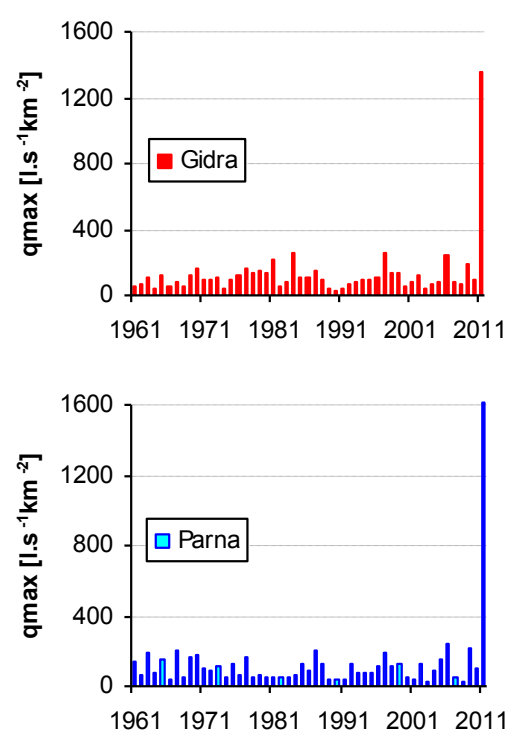

a)

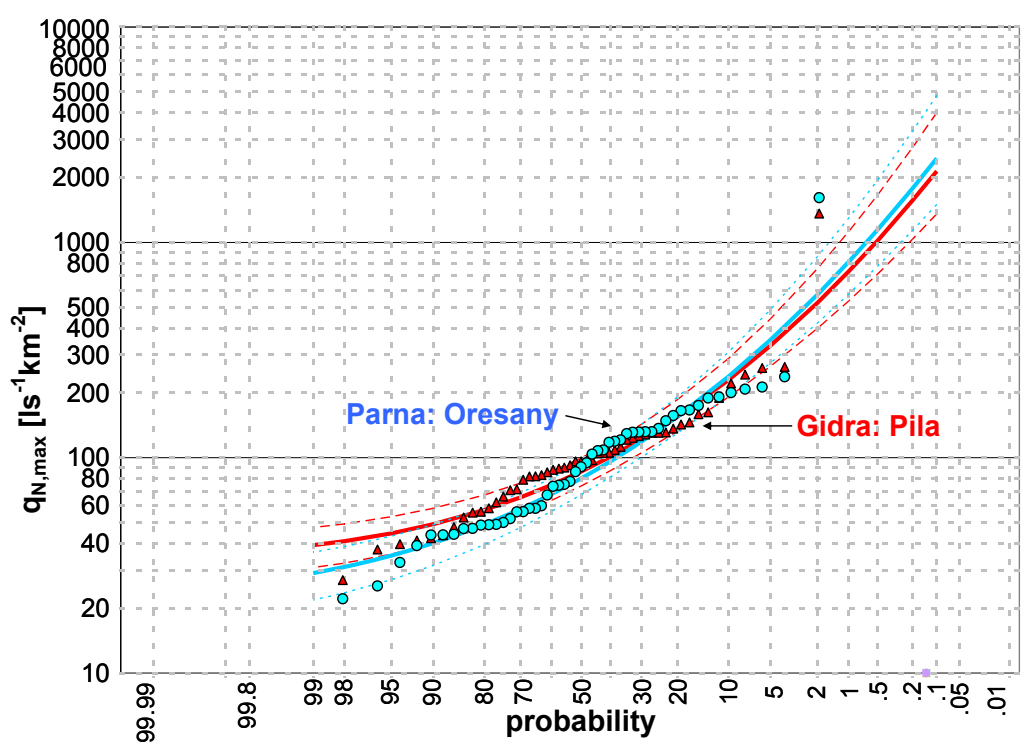

b)

Fig. 5a) Maximum annual Gidra and Parná specific runoff time series within period 1961-June 2011.

Fig. 5b) Theoretical Gidra and Parná annual peak specific runoff exceedance probability curves (Log-Pearson, type III.), period 1961-2011: $q(5)$ and $q(95)$ - confidence limits.

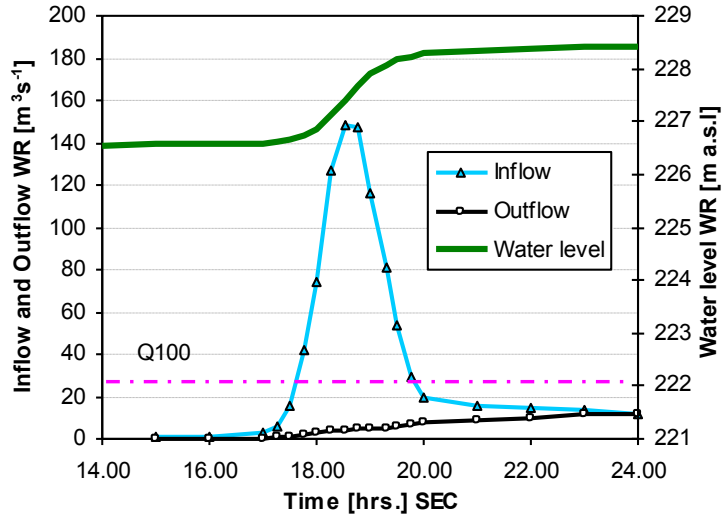

a)

Fig. 6. a) Flash flood wave transformation with water reservoir Horné Orešany according to Spál (2011); b) Flood water level on the 8th June 2011 (Photo: M. Boháček); c) Normal water level on the 26th July 2011, (Photo: P. Pekárová). 
T a b 1 e 4. Gidra and Parná T-year maximum discharges.

\begin{tabular}{|c|c|c|c|c|c|c|}
\hline$T$ & 20 & 50 & 100 & 200 & 500 & 1000 \\
\hline Gidra: Píla 1961-2011, $Q$ & 11 & 17 & 24 & 33 & 51 & 70 \\
\hline$Q(5)$ & 15 & 25 & 37 & 54 & 90 & 131 \\
\hline$Q(95)$ & 9 & 13 & 18 & 23 & 34 & 44 \\
\hline Parná: Orešany 1961-2011, Q & 13 & 22 & 31 & 43 & 67 & 93 \\
\hline$Q(5)$ & 18 & 33 & 49 & 74 & 124 & 182 \\
\hline$Q(95)$ & 10 & 16 & 22 & 29 & 43 & 57 \\
\hline
\end{tabular}

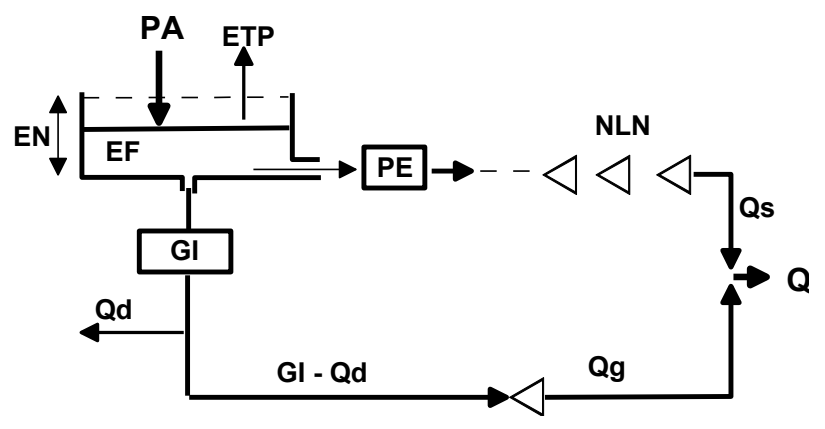

Fig. 7. Schematic representation of the NLC model structure. $(P A-$ input precipitation, $P E$ - effective precipitation, $E T P$ - evapotranspiration, $Q s$ - direct runoff, $G I$ - groundwater input, $Q g$ - groundwater runoff, $Q$ - total runoff, $Q d$ - deep percolation, $E N$ and $E F$ are storage parameter and actual water content of the unsaturated zone).

\subsection{NLC model calibration}

Model was calibrated, using data of the 7th June 2011 waves on Gidra at Píla, and Parná at Horné Orešany. Calibration results can be seen in Fig. 8a)b), numerically it is expressed by the Nash's criterion - 0.914 (Gidra), and 0.931 (Parná).

For Gidra, precipitation volume was $3.333 \mathrm{mil} . \mathrm{m}^{3}$ of water, runoff volume up to $7.00 \mathrm{hrs}$. next day $0.521 \mathrm{mil} . \mathrm{m}^{3}$ of water, and simulated runoff volume $0.531 \mathrm{mil} . \mathrm{m}^{3}$. During the flood wave (up to $7.00 \mathrm{hrs}$.), total runoff amounts to $16.6 \%$ of the rainfall volume. Direct runoff was 0.382 mil. $\mathrm{m}^{3}$ of water, i.e. $11.4 \%$ of the rainfall. Results for both of the rivers are in Tab. 5 .

\subsection{Rainfall scenarios development, and runoff simulation}

Catastrophic rainfall scenario for the Gidra and the Parná basins was developed on basis of works by $D u b$ (1941 and 1955). Author presented extreme rainfall intensities in relation to their duration, for several regions of Slovakia.

For the Gidra River, the longest river network length was estimated to appr. 10 kilometers. This, for conservative estimate, corresponds to the critical river basin time of app. $1.45 \mathrm{hrs}$. To such dura- tion, the highest possible rainfall intensities correspond as high as $i=2.08 \mathrm{~mm} \mathrm{~min}^{-1}$, or values acceptable for sewer capacity design $i=1.37 \mathrm{~mm}$ $\min ^{-1}$. These values were quoted by $D u b(1955)$ as the highest from unknown source by Haeuser (Dresden, appr. 1940). Dub's own values for our territory for that duration (105 min. $-1.45 \mathrm{hrs}$ ) were stated as $i=1.20 \mathrm{~mm} \mathrm{~min}^{-1}$.

Based upon this information, catastrophic input storm rainfall was developed for both catchments. It is a time sequence of seven 15-minutes rainfall events, each of $16.5 \mathrm{~mm}$ rainfall amount, thus forming the total rainfall depth of $115.5 \mathrm{~mm}$. Its time course (after some temporal shape modification) is shown in Fig. 9a).

In case of Gidra, with such extreme rainfall scenario, simulated peak flood wave discharge would amount to $105.8 \mathrm{~m}^{3} \mathrm{~s}^{-1}$, which means a specific runoff peak of $3.211 \mathrm{~m}^{3} \mathrm{~s}^{-1} \mathrm{~km}^{-2}$. Total 24-hours runoff would be $0.821 \mathrm{mil} . \mathrm{m}^{3}$, which represents $21.6 \%$ of the rainfall volume $\left(3.8 \mathrm{mil} . \mathrm{m}^{3}\right)$. Direct runoff would be $0.811 \mathrm{mil} . \mathrm{m}^{3}$, i.e. $21.3 \%$ of the input storm rainfall (Fig. 9b).

In case of Parná, with extreme rainfall scenario of $115.5 \mathrm{~mm}$ ( $4.4 \mathrm{mil} . \mathrm{m}^{3}$ on the catchment area), peak flood wave discharge would amount to $144.7 \mathrm{~m}^{3} \mathrm{~s}^{-1}$, which means a specific runoff peak of $3.821 \mathrm{~m}^{3} \mathrm{~s}^{-1} \mathrm{~km}^{-2}$. Total 24-hourly runoff would be $1.303 \mathrm{mil} . \mathrm{m}^{3}$, which represents $29.6 \%$ of the rainfall volume. Direct runoff would be $1.283 \mathrm{mil} . \mathrm{m}^{3}$, i.e. $29.1 \%$ of the rainfall (Fig. $9 \mathrm{c}$ ).

\section{Discussion}

The runoff coefficients during the June 2011 flood in the Gidra (0.16) and the Parná (0.22) catchments are relatively low, compared to 0.8 value, evaluated from the Svinka 1988 flood (Svoboda and Pekárová, 1998). Also data from the Belá River representative basin from four historically highest floods, yield flood runoff coefficient values from 0.48 to 0.52 (Pekárová et al., 2010). From the NLC model results it follows, that the direct runoff from the Small Carpathians during the described flood 

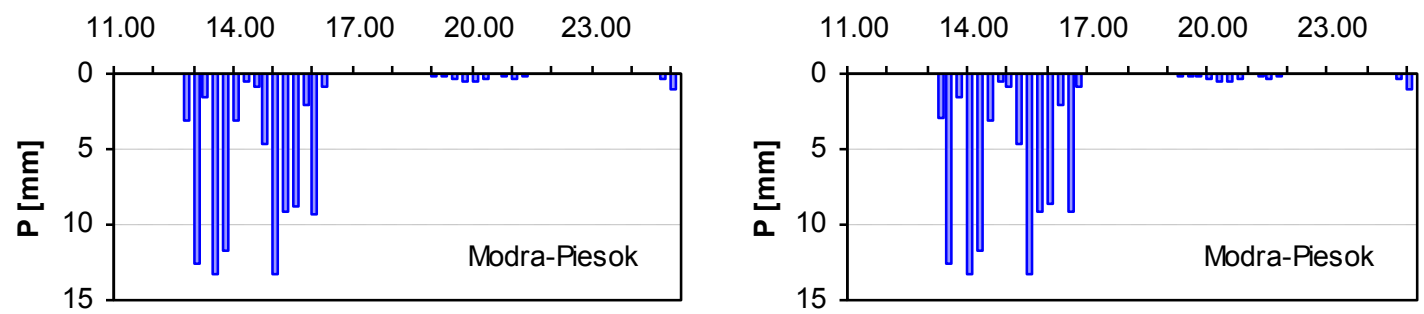

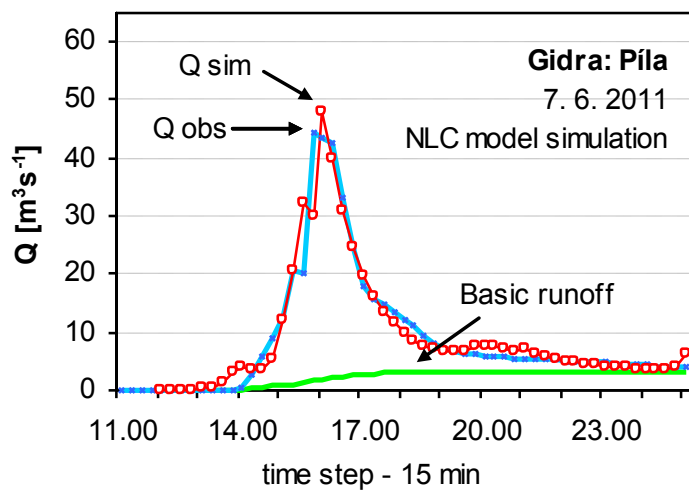

a)

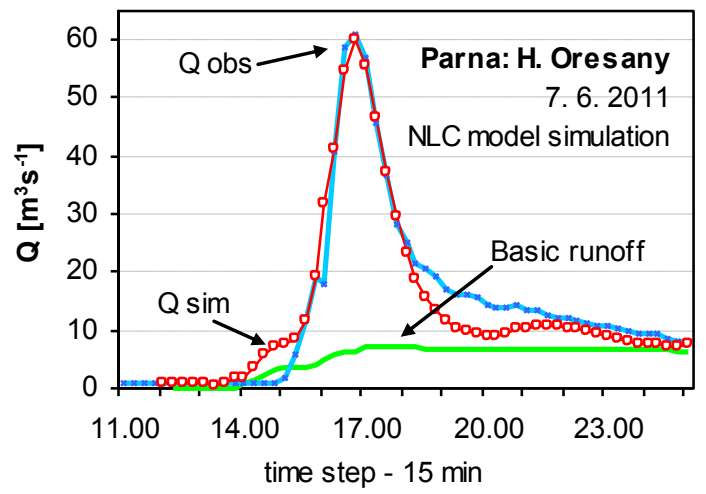

b)

Fig. 8. Rainfall depth, measured discharges (points), the simulated ones (red line), and the simulated basic runoff (green bottom line), at 15-minutes intervals, for a) Gidra and b) Parná.

T a b 1 e 5. The runoff, precipitation volumes and runoff coefficients $K$ during the flood of 7 th June 2011, within 18 hours.

\begin{tabular}{|c|c|c|c|c|c|c|}
\hline River & $\begin{array}{l}\text { Precipitation } \\
\quad\left[\text { mil. } \mathrm{m}^{3}\right]\end{array}$ & $\begin{array}{c}\text { Total } R \text { obs. } \\
{\left[\text { mil. } \mathrm{m}^{3}\right]}\end{array}$ & $\begin{array}{c}\text { Total } R \text { sim } \\
{\left[\text { mil. } \mathrm{m}^{3}\right]}\end{array}$ & $K$ tot & $\begin{array}{c}\operatorname{direct} R \operatorname{sim} \\
{\left[\mathrm{mil} . \mathrm{m}^{3}\right]}\end{array}$ & $K$ dir \\
\hline Gidra & 3.333 & 0.521 & 0.531 & 0.16 & 0.382 & 0.11 \\
\hline Parná & 3.824 & 0.849 & 0.847 & 0.22 & 0.462 & 0.12 \\
\hline
\end{tabular}

amounted only to some $11-12 \%$ of the fallen causative rainfall. This witnesses fair water holding capacity of the Small Carpathian forested catchments. These results are in agreement with those of Merz and Blöschl (2003), indicating that during flash floods in Austria, the flood runoff coefficients were lower as compared with those of the mean annual discharge runoff coefficients.

The rainfall and discharge data from these two small catchments gave us valuable information not only on regional flood runoff formation in general, but on the real flood protection possibilities as well. Those meteorological processes (particularly storm rainfall) taking part in their origin, local and temporal inception, do not depend upon possible human intervention. The real interest of hydrologists and water managers is to study flood generating processes over the whole catchment. Parts of its „river network" do not consist only of its main river channel and its tributaries, but also of its other parts, like river channels of the higher orders, ditches along main and adjoining communications, agricultural fields draining ditches ending often directly in community's yards, and not least also of the field's furrows. If any of these river network parts water carrying capacity is not sufficient to absorb inflow from the intensive rain, smaller or larger "flood“ starts. The above described events (and not only those) document these facts expressively enough. Rainfall-runoff modeling methods showed up also to be a suitable tool for these floods assessment. These methods should be useful not only for these remarkable events reconstruction, but also for extreme hypothetical cases constitution. Such precipitation events occurrence, meteorologists hold for possible, though extremely rare.

There are several tens (perhaps hundreds) of smaller communes endangered by flooding from small streams, brooks or creeks with small catchments, comparable with those described above. Critical rainfall occurrence probability on each of them individually, is small. However, probability 
that during the summer stormy season over our territory such event occurs over an individual community (from those hundreds of small catchments), is substantially higher.
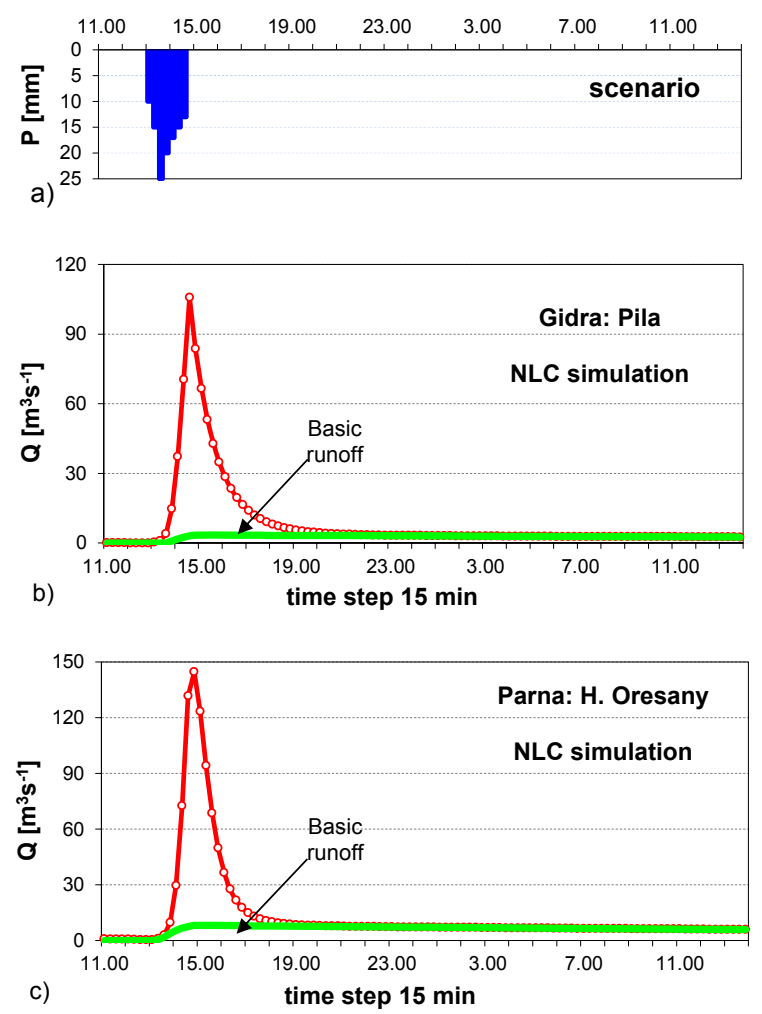

Fig. 9a) Catastrophic rainfall (115mm of $1.45 \mathrm{hrs}$ duration), time interval $15 \mathrm{~min}$.; b) Catastrophic rainfall $(115 \mathrm{~mm}$ of 1.45 hrs duration) - runoff simulation, Gidra - Píla, time interval 15 minutes, total and basic runoff; c) Catastrophic rainfall (115mm of $1.45 \mathrm{hrs}$ duration) - runoff simulation, Parná Horné Orešany, time interval 15 minutes, total and basic runoff.

From the long-term point of view, discharges in Slovakia, in general, decreased in period 1931-1995. Since 1996, however, the rainfall amounts have been higher and the year 2010 was extremely wet. Therefore, the recent occurrence of more flood events in Slovakia should not necessarily be a climate change consequence. It can easily be manifestation of a long-term natural rainfall and runoff variability.

\section{Conclusions}

From the NLC model results with extreme rainfall scenario in the case of the Gidra River it follows, that total 24-hours runoff would be $0.821 \mathrm{mil.}^{3}$, and direct runoff would be $0.811 \mathrm{mil} . \mathrm{m}^{3}$, i.e.
$21.3 \%$ of the input storm rainfall. In the case of the Parná River, the total 24-hourly runoff would be $1.303 \mathrm{mil.} \mathrm{m}^{3}$, and direct runoff would be 1.283 mil. $\mathrm{m}^{3}$, i.e. $29.1 \%$ of the rainfall. Such water volumes cannot be effectively stored in the natural catchment environment - soil, vegetation cover (Fodor et al, 2011). Either such storage (retention) volumes need to be artificially created, or each part of the catchment river network elements adapted to such discharge carrying capacity, as to be able to control the storm rainfall inflow. Or to combine both.

For the design of effective flood protection measures, it is essential to know the critical flood peak discharge and flood wave volume, we need to be protected against. For that first step, a suitable tool (except others), is exactly mathematical rainfall-runoff modeling. Its use, we believe, has been sufficiently documented, as well as value of the flood data (both, meteorological and hydrological), estimated from records and from the realized field survey.

Acknowledgement. This work was supported by the project VEGA 02/010/11.

\section{REFERENCES}

ADÁMYOVÁ S., 1989: Long-term year discharges, their territorial and time variability. In: Collection of papers of SHMI, 29/II. ALFA, Bratislava, 13-148.

ARISTEIDIS G., KOUTROULIS A., IOANNIS K., TSANIS J., 2010: A method for estimating flash flood peak discharge in a poorly gauged basin: Case study for the 13-14 January 1994 flood, Giofiros basin, Crete. Greece J. Hydrol., 385, 150-164.

BLAS̆KOVIČOVÁ L., HORVÁT O., HLAVČOVÁ K., KOHNOVÁ S., SZOLGAY J., 2011: Methodology for Post-Event Analysis of Flash Floods - Svacenický Creek case study. Contributions to Geophysics and Geodesy, in press.

BORGA M., ANAGNOSTOU E.N., BLÖSCHL G., CREUTIN J.D., 2010: Flash floods: observations and analysis of hydrometeorological controls. J. Hydrol., 394, 1-2, 1-3, doi: 10.1016/ j.jhydrol.2010.07.048.

BORGA M., ANAGNOSTOU E.N., BLÖSCHL G., CREUTIN J.D., 2011: Flash flood forecasting, warning and risk management: The HYDRATE project. Environmental Science \& Policy, 14, 7, 834-844.

BRAUD I., ROUX H., ANQUETIN S., MAUBOURGUET M., MANUS C., VIALLET P., DARTUS D., 2010: The use of distributed hydrological models for the Gard 2002 flash flood event: Analysis of associated hydrological processes. J. Hydrol., 394, 1-2, 162-181.

DUB O., 1941: Režim vel'kých vôd na malých tokoch. Publikácia štátneho hydrologického a meteorologického ústavu v Bratislave.

DUB O., 1955: Všeobecná hydrológia Slovenska. Bratislava, SVTL. 
DZUBÁK M., HLAVČOVÁ K., MOLNÁR P., SZOLGAY J., TIHLÁRIK R., 1995: Extrémne odtokové pomery v povodi Kysuce. Čast' 1. Zrážkový a povodňový režim. J. Hydrol. Hydromech., 43, 1-2, 28-56.

FODOR, N., SÁNDOR, R., ORFÁNUS, T., LICHNER, L., RAJKAI, K., 2011: Evaluation method dependency of measured saturated hydraulic conductivity. Geoderma, 165 , $1,60-68$

GAUME E., BAIN V., BERNARDARA P., NEWINGER O., BARBUC M., BATEMAN A., BLAŠKKOVIČOVÁ L., BLÖSCHL G., BORGA M., DUMITRESCU A., DALIAKOPOULOS I., GARCIA J., IRIMESCU A., KOHNOVA S., KOUTROULIS A., MARCHI L., MATREATA S., MEDINA V., PRECISO E., SEMPERE-TORRES D., STANCALIE G., SZOLGAY J., TSANIS J., VELASCO D., VIGLIONE A., 2009: A collation of data on European flash floods. J. Hydrol. 367, 70-78. doi: 10.1016/j.jhydrol.2008.12.028.

GAUME E., GAÁL L., VIGLIONE A., SZOLGAY J., KOHNOVÁ S., BLÖSCHL G., 2010: Bayesian MCMC approach to regional flood frequency analyses involving extraordinary flood events at ungauged sites. J. Hydrol., 394, $1-2,101-117$

HLUBOCKÝ B., 1989: Mean precipitation totals on catchments. In: Collection of papers of SHMI, 29/I. ALFA, Bratislava, 203-263.

HP ČSSR, 1965: Hydrological conditions of the Czechoslovak Socialist Republic. Hydrometeorological Institute, Prague, $414 \mathrm{pp}$

KLIMENT Z., MATOUŠKOVÁ M., LEDVINKA O., KRÁLOVEC V., 2011: Trend analysis of rainfall-runoff regimes in selected headwater areas of the Czech Republic. J. Hydrol. Hydromech., 59, 1, 36-50.

MERZ R., BLÖSCHL G., 2003: A process typology of regional floods. Water Resour. Res., 39, 12, 1340, doi: 10.1029/2002WR001952.

MAJERČÁKOVÁ O., MAKEL' M., ŠŤASTNÝ P., KUPČO M., RONČÁK P., 2004: Selected flash floods in the Slovak Republic. GWP report. Slovak Hydrometeorological Institute, Bratislava, $34 \mathrm{pp}$.

PARAJKA J., KOHNOVÁ S., BÁLINT G., BARBUC M., BORGA M., CLAPS P., CHEVAL S., GAUME E., HLAVČOVÁ K., MERZ R., PFAUNDLER M., STANCALIE G., SZOLGAY J., BLOÖSCHL G., 2010: Seasonal characteristics of flood regimes across the Alpine- Carpathian range. J. Hydrol. 394, 1-2, 78-89, doi: 10.1016/ j.jhydrol.2010.05.015.

PEKÁROVÁ P., PEKÁR J., 1998: The chemical regime and interaction of surface- and groundwater in the Small Carpathian region. Ekológia (Bratislava), 17, 4, 391-406.

PEKÁROVÁ P., MIKLÁNEK P., PEKÁR J., ŠKODA P., HALMOVÁ D., 2010: Flood regime analysis in the High Tatra Mountain Bela River basin. Edited by Hubert HOLZMANN, Reinhold GODINA and Gabriele MÜLLER, 13th Biennial Conference ERB 2010, HYDROLOGICAL RESPONSES OF SMALL BASINS, TO A CHANGING ENVIRONMENT, 5-8 September 2010, Seggau Castle, Austria, Book of Abstracts, Vienna, Institute of Water Management ISBN 978-3-900962-90-6, 195-198.

SPÁL M., 2011: June flood in Small Carpathian, or what is the 100-year flood? (In Slovak.) In: Hlas Váhu, XXI, 4-5, 1-4, (journal of the Slovak water management directorate employees).

SVOBODA A., 1987: Two-componed nonlinear rainfall-runoff model NLC. (In Slovak.) J. Hydrol. Hydromech., 35, 6, 661-663.

SVOBODA A., PEKÁROVÁ P., 1998: The catastrophic flood of July 1998 in the Malá Svinka catchment - its simulation. (In Slovak.) J. Hydrol. Hydromech., 46, 6, 356-365.

ŠAMAJ F., VALOVIČ Š., BRÁZDIL R., 1985: Denné úhrny zrážok s mimoriadnou výdatnost'ou v ČSSR v období 1901-1980. In: Zborník prác SHMÚ 24. ALFA, Bratislava, 9-112.

ŠRAJ M., DIRNBEK L., BRILLY M., 2010: The influence of effective rainfall on modeled runoff hydrograph. .J. Hydrol. Hydromech., 58, 1, 3-14.

ŠŤASTNÝ P., MAJERČÁKOVÁ O., 2003: Reconstruction of the flood in Strba on July 2001. In: Proceedings of 'Hydrology at the Beginning of the 21st Century: Vision and Reality', Smolenice, May 5-7, 2003. Hydrological Institute SAS, Slovak Committee for Hydrology, Slovak IGBP Committee, (in Slovak).

Received 12 September, 2011 Accepted 13 March, 2012 